\title{
Analysis Financial Distress Prediction With Model Altman Z-Score, Zmijewski, And Grover In The Sub Sector Retail Listed On The Indonesian Stock Exchange (Idx) 2014-2018 Period
}

\author{
Megalasmi Bellyra Helastica $^{1}$, V. Santi Paramita ${ }^{2}$ \\ \{megalasmibellyrahelastica26@gmail.com ${ }^{1}$, santi.pramit@gmail.com ${ }^{2}$ \}
}

Department of Management, Faculty of Economics and Business Universitas Jendral Acmad Yani, Indonesia ${ }^{1}$, Department of Management, Faculty of Economics and Business Universitas Jendral Achmad Yani, Indonesia ${ }^{2}$

\begin{abstract}
Financial distress is a condition when a company experiences financial difficulties. Financial distress is an early warning for companies not to go bankrupt. Financial distress analysis is useful for investors, government, auditors, and company management. Financial distress can be predicted using the Altman Z-Score, Zmijewski, and Grover models. The research sample was 8 retail sub-sector companies listed on the Indonesia Stock Exchange for the period 2014-2018. The main objective of this research is to predict the financial distress of companies in the retail sub-sector and to analyze the level of prediction accuracy from the financial distress prediction model.
\end{abstract}

Keywords: Financial Distress, Bankruptcy, Altman Z-Score, Zmijewski, and Grover.

\section{Introduction}

The increase in the global economy has triggered intense competition businesses that have advantages service and product quality. The new realm of the trade industry in the era of globalization e-commerce is one of the industries whose growth is starting to grow rapidly in Indonesia. Indonesia has become one of the countries with the highest e-commerce growth in the world because many business actors have expanded their business by digitizing in the past few years (wartaekonomi.co.id, 2019). The growth of the e-commerce trade industry certainly has a direct impact on the retail trade industry sub-sector. Coordinating Minister for Economic Affairs Darmin Nasution stated that the closure of many retail outlets was due to the changing shopping style of society, where people currently prefer to shop online (Liputan6.com, 2019). In 2014 on February 11, in the plenary session of the Dewan Perwakilan Rakyat (DPR), the Rancangan Undang-Undang (RUU) was passed, where the bill was considered to be quite partial to the people's market, cooperatives, and small, medium, and micro-business actors. The government also regulates operations and implements zoning from retail, supermarkets, and supermarkets. These businesses are considered to be capable of disrupting and detrimental to the people's market, cooperatives, and small, medium and micro business actors so that the Trade Law is considered to limit the movement of modern retail (Kabarbisnis, 2014). This has increasingly influenced the growth of the retail industry.

Retail sales growth data tends to fluctuate and decline in 2012-2018. Based on the analysis of the financial statements of companies listed in the retail sub-sector on the IDX, 9 companies experienced a decrease in negative net income or a decline in financial conditions in their 
operations for more than one year, this is following the characteristics of financial distress stated by Hofer (1980), Whitaker (1999), and Listyarini, et al. (2016) in [1]. Another indicator if a company experiences financial distress [2] is the company experiencing delisted from the capital market. Delisted is the delisting of the issuer's shares from the stock exchange, where the write-off is carried out based on the company's assessment.

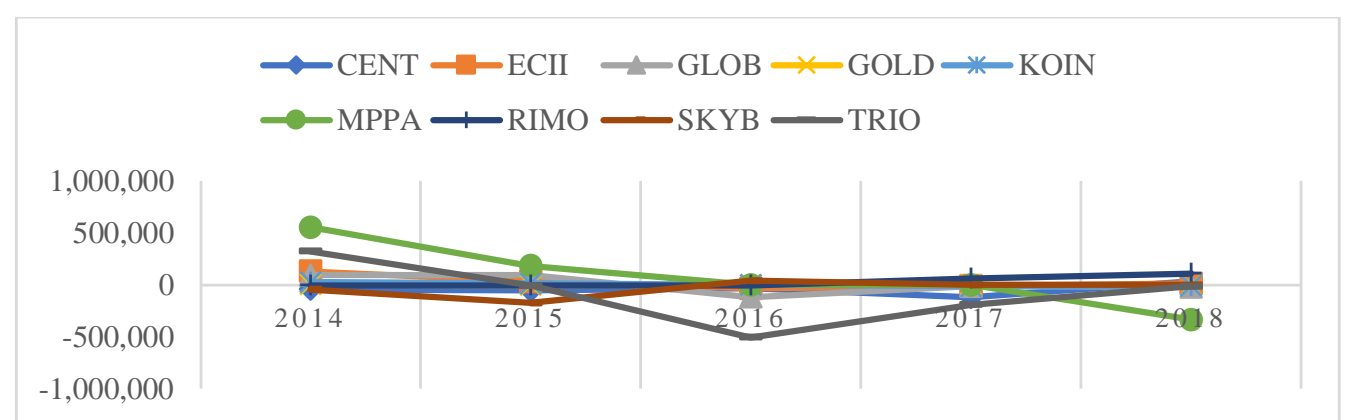

Fig 1. Companies in the Retail Sub-Sector Experiencing Negative Profits for More Than One Year for the 2014-2018 Period

Source:www.idx.co.id (data reprocessed, 2019)

Financial distress analysis is carried out that the company knows the early signs of bankruptcy. The earlier the company knows the sign, the better it is for management because management can make improvements directly [3]. Financial distress prediction research has often been conducted in Indonesia, including research conducted by [1], [2], [4], [5], [6], and [7]. Based on the description above, the problem in this study is "How financial distress prediction in the retail sub-sector listed on the Indonesia Stock Exchange (BEI) for the 20142018 period uses the Altman Z-Score, Zmijewski, and Grover models" and "Which prediction model is most accurate in predicting financial distress in the retail sub-sector listed on the Indonesia Stock Exchange (BEI) for the 2014-2018 period". This study seeks to predict corporate financial distress in the retail sub-sector and analyze the level of prediction accuracy from the financial distress prediction model.

The results of this study are expected to be used as material for the attention of various parties concerned because by knowing the company is experiencing financial distress, these parties can determine actions and decisions to improve the situation.

\section{Review of Literature}

\subsection{Financial Distress}

Financial distress is now a common occurrence in a competitive market environment. Financial distress is the time before the company goes bankrupt [9]. Financial distress also has several types of definitions according to Brigham \& Gapenski (1997) in [2] namely, economic failure, business failure, technical insolvency, insolvency bankruptcy, and legal bankruptcy. Financial difficulties are a very important indicator for stakeholders such as investors, government, auditors, and company management. 


\subsection{Financial Distress Prediction Model}

The financial distress prediction model is one of the techniques and tools used to predict the possibility of corporate bankruptcy in the future, by combining financial ratios [6]. Bankruptcy can be experienced by large or small companies so the company management must prevent potential bankruptcy [10]. Atman Z-Score, Zmijewski, and Grover models are 3 of the many other financial distress prediction models that can be used to predict bankruptcy in companies.

\subsection{Bankruptcy}

Company bankruptcy is usually characterized by difficulties to finance, production activities, difficulties in attracting loans from creditors, and refinancing [4]. Bankruptcy according to Peter and Yoseph (2011) in [1] is a company condition when it experiences insufficient funds to run its business. Bankruptcy can be caused by general factors, company external factors, and company internal factors [8]. In Indonesia bankruptcy is regulated in UU No.1 of 1998, which states that a debitor who has two or more creditors and cannot pay at least one overdue debt that cannot be collected, is declared bankrupt by an authorized court decision, either on his own request. , or at the request of one or more creditors. This application can also be submitted by the prosecutor for the public interest.

\section{Materials and Method}

The sampling technique in this study was purposive sampling, so the research sample consisted of 8 companies from a total population of 9 retail sub-sector companies listed on the IDX for the 2014-2018 period. The data source of this research is a secondary data source, in the form of financial reports of the research object published by the Indonesia Stock Exchange (BEI). The variables used in this study are:

1. Altman Z-Score Model

The formula to use:

$$
Z "=6.56 \mathrm{X} 1+3.26 \mathrm{X} 2+6.72 \mathrm{X} 3+1.05 \mathrm{X} 4
$$

The financial ratios uses in the Altman Z-Score model are:

$\mathrm{Z}$ " $=\mathrm{Z}-$ Score

X1 = Working Capital / Total Assets

$\mathrm{X} 2=$ Retained Earnings $/$ Total Assets

X3 = Earnings Before Interest and Taxes / Total Assets

$\mathrm{X} 4$ = Book Value Equity / Total Liabilities [11]

Or according to [10]

X1 = Net Working Capital / Total Assets

X2 $=$ Retained Earnings $/$ Total Assets

X3 = EBIT / Total Assets

X4 = Total Equity / Total Liability

The classification or category of healthy, gray area and bankrupt companies is based on the Altman Z-Score model, namely:

a. If $Z^{\prime \prime}<1.1$, then the company is included in the category of financial distress/bankruptcy,

b. If $1.1<Z^{\prime \prime}<2.6$, then the company is included in the gray area category 
c. If Z" > 2.6, then the company is included in the healthy category

2. Zmijewski Model

The formula used: [8]

$\mathrm{X}$ - Score $=-4,3-4,5 \mathrm{X} 1+5,7 \mathrm{X} 2-0,004 \mathrm{X} 3$

The financial ratios uses in the Zmijewski model are:

$\mathrm{X} 1=$ Return On Asset (EAT / Total Assets)

X2 = Debt Ratio (Total Liabilities / Total Assets)

X3 = Current Ratio (Current Assets / Current Liabilities)

The classification or category of healthy and bankrupt companies is based on the Zmijewski model, namely:

a. If $\mathrm{X}>0$, then the company is included in the category of financial distress/bankruptcy,

b. If $\mathrm{X}<0$, then the company is included in the healthy category

3. Grover Model

The formula used: [6]

G-Score $=1,650 \mathrm{X} 1+3,404 \mathrm{X} 2-0,016 \mathrm{ROA}+0,057$

The financial ratios uses in the Grover model are:

$\mathrm{X} 1$ = Working capital / Total assets

$\mathrm{X} 2=$ Total assets / Earnings before interest and taxes

$\mathrm{ROA}=$ Net income $/$ Total assets

The classification or category of healthy and bankrupt companies is based on the Grover model, namely:

a. If $\mathrm{G} \leq-0.02$, then the company is included in the category of financial distress/bankruptcy,

b. If $\mathrm{G} \geq 0.01$ then the company is included in the healthy category

The accuracy test of the financial distress prediction model in this study uses the Type II error. The level of e error is known if the financial distress prediction model predicts that the research sample experiences distress, while the actual condition of the company does not experience financial distress or delisted [12]. The following is the formula for testing the accuracy of the financial distress prediction model and the Type II error:

Accuracy Level $=($ Number of Correct Predictions $/$ Number of Samples $) \times 100 \%$

Type II Error $=($ Number of Errors Type II / Number of Samples $) \times 100 \%$ 


\section{Result and Discussion}

Financial ratios are one of the methods developed to analyze financial distress in companies and the Altman Z-Score, Zmijewski, and Grover models are models compiled from various financial ratios.

Research [13] states that the liquidity ratio in the financial distress prediction model has a positive effect on financial distress. High liquidity results in higher Altman Z-Score, Zmijewski, and Grover values so that the company can be said to be healthier, for the leverage ratio is stated to have a negative effect on financial distress. High leverage results in the lower Altman ZScore and Zmijewski values and companies that cannot make good use of their debt will be at risk of experiencing financial distress, and the profitability ratio according to [14] is stated to have a significant influence in predicting financial distress. Because of the higher the profitability, the smaller the company's chances of experiencing financial distress.

\section{Altman Z-Score Model}

The following is a table of financial distress prediction scores using the Altman Z-Score model in the retail sub-sector listed on the Indonesia Stock Exchange (BEI) in 2014-2018.

Table 1 Score Financial Distress Prediction Model Altman Z-Score

\begin{tabular}{|c|c|c|c|c|c|c|c|c|c|c|c|}
\hline \multirow{3}{*}{$\begin{array}{c}\text { No } \\
1\end{array}$} & \multirow{3}{*}{$\begin{array}{c}\text { CODE } \\
\text { CENT }\end{array}$} & \multicolumn{10}{|c|}{ Financial Distress Prediction } \\
\hline & & \multicolumn{2}{|c|}{2014} & \multicolumn{2}{|c|}{2015} & \multicolumn{2}{|c|}{2016} & \multicolumn{2}{|c|}{2017} & \multicolumn{2}{|c|}{2018} \\
\hline & & 2,13 & GA & 1,15 & GA & 3,81 & $\mathrm{H}$ & 1,87 & GA & 1,93 & GA \\
\hline 2 & ECII & 6,3 & $\mathrm{H}$ & 5,15 & $\mathrm{H}$ & 4,56 & $\mathrm{H}$ & 4,68 & $\mathrm{H}$ & 4 & $\mathrm{H}$ \\
\hline 3 & GLOB & 3,52 & $\mathrm{H}$ & 3,35 & $\mathrm{H}$ & $-12,99$ & B & $-13,78$ & B & $-5,16$ & B \\
\hline 4 & KOIN & 1,87 & GA & 1,36 & GA & 2,38 & GA & 0,97 & B & 0,57 & B \\
\hline 5 & MPPA & 4,13 & $\mathrm{H}$ & 3,22 & $\mathrm{H}$ & 2,2 & GA & $-3,24$ & B & $-2,14$ & B \\
\hline 6 & RIMO & $-5,05$ & B & $-2,2$ & B & $-1,9$ & B & 7,2 & $\mathrm{H}$ & 4,7 & $\mathrm{H}$ \\
\hline 7 & SKYB & 2,28 & GA & 2,16 & GA & 28,12 & $\mathrm{H}$ & $-7,74$ & B & 30,4 & $\mathrm{H}$ \\
\hline 8 & TRIO & 5,46 & $\mathrm{H}$ & $-1,13$ & B & $-6,8$ & B & $-5,06$ & B & $-1,12$ & B \\
\hline
\end{tabular}

Financial distress prediction model Altman Z-Score in the retail sub-sector in 2014, there are 4 companies predicted to be in good health, 3 companies predicted to be in the gray area, and 1 company predicted to be in bankruptcy. In 2015, 3 companies are predicted to be in good health, 3 companies are predicted to be in a gray area, and 2 companies are predicted to be in bankruptcy. In 2016, 3 companies are predicted to be in good health, 2 companies in the gray area, and 3 companies in bankruptcy. In 2017, 2 companies are predicted to be in healthy condition, 1 company is in a gray area, and 5 companies are predicted to be bankrupt. Meanwhile, in 20183 companies are predicted to be in good health, 1 in a gray area and 5 companies are predicted to be in bankruptcy or financial difficulties. The greater the $\mathrm{Z}$ "score, the healthier the company or not experiencing financial distress.

2. Zmijewski model

The following is a table of financial distress prediction scores using the Zmijewski model in the retail sub-sector listed on the Indonesia Stock Exchange (BEI) in 2014-2018. 
Table 4 Score Financial Distress Prediction Model Zmijewski

\begin{tabular}{|c|c|c|c|c|c|c|c|c|c|c|c|}
\hline \multirow{3}{*}{$\begin{array}{c}\text { No } \\
1\end{array}$} & \multirow{3}{*}{$\frac{\text { CODE }}{\text { CENT }}$} & \multicolumn{10}{|c|}{ Financial Distress Prediction } \\
\hline & & \multicolumn{2}{|c|}{2014} & \multicolumn{2}{|c|}{2015} & \multicolumn{2}{|c|}{2016} & \multicolumn{2}{|c|}{2017} & \multicolumn{2}{|c|}{2018} \\
\hline & & $-2,6233$ & $\mathrm{H}$ & $-3,1832$ & $\mathrm{H}$ & $-3,0009$ & $\mathrm{H}$ & $-2,2489$ & $\mathrm{H}$ & $-1,9519$ & $\mathrm{H}$ \\
\hline 2 & ECII & $-3,9821$ & $\mathrm{H}$ & $-4,0113$ & $\mathrm{H}$ & $-3,7978$ & $\mathrm{H}$ & $-3,7595$ & $\mathrm{H}$ & $-3,721$ & $\mathrm{H}$ \\
\hline 3 & GLOB & $-0,5739$ & $\mathrm{H}$ & $-0,5739$ & $\mathrm{H}$ & 60,4864 & B & 66,6004 & B & $-4,1832$ & $\mathrm{H}$ \\
\hline 4 & KOIN & $-0,0718$ & $\mathrm{H}$ & $-0,5703$ & $\mathrm{H}$ & 0,464 & B & 0,6288 & B & 0,7702 & B \\
\hline 5 & MPPA & $-1,82$ & $\mathrm{H}$ & $-1,25$ & $\mathrm{H}$ & $-0,6973$ & $\mathrm{H}$ & 1,1952 & B & 0,8818 & B \\
\hline 6 & RIMO & $-1,232$ & $\mathrm{H}$ & 15,8954 & B & 12,9077 & B & $-3,607$ & $\mathrm{H}$ & $-3,4295$ & $\mathrm{H}$ \\
\hline 7 & SKYB & $-0,3485$ & $\mathrm{H}$ & 9,5176 & B & $-9,7442$ & $\mathrm{H}$ & $-4,4838$ & $\mathrm{H}$ & $-3,8143$ & $\mathrm{H}$ \\
\hline 8 & TRIO & 0,0415 & $\mathrm{~B}$ & $-4,2567$ & $\mathrm{H}$ & 0,8906 & B & $-0,3215$ & $\mathrm{H}$ & $-4,1878$ & $\mathrm{H}$ \\
\hline
\end{tabular}

Financial distress prediction using the Zmijewski model in 2014, 7 companies were in a healthy condition, and 1 company that was in a bankrupt condition. Meanwhile, in 2015, 6 companies were predicted to be in good health and 2 companies were in bankruptcy, in 20164 companies were predicted to be in good health and vice versa. In 2017, 5 companies are predicted to be in good health and 3 others are predicted to be in bankruptcy or financial difficulties. And in 2018, 6 companies are predicted to be in good health and 2 companies are predicted to be in bankruptcy. In Zmijewski's model the smaller the $\mathrm{X}$ score, the better the company's condition.

3. Grover Model

The following is a table of financial distress prediction scores using the Grover model in the retail sub-sector listed on the Indonesia Stock Exchange (BEI) in 2014-2018.

Table 5 Score Financial Distress Prediction Model Grover

\begin{tabular}{|c|c|c|c|c|c|c|c|c|c|c|c|}
\hline \multirow{3}{*}{$\begin{array}{c}\text { No } \\
1\end{array}$} & \multirow{3}{*}{$\begin{array}{c}\text { CODE } \\
\text { CENT }\end{array}$} & \multicolumn{10}{|c|}{ Financial Distress Prediction } \\
\hline & & \multicolumn{2}{|c|}{2014} & \multicolumn{2}{|c|}{2015} & \multicolumn{2}{|c|}{2016} & \multicolumn{2}{|c|}{2017} & \multicolumn{2}{|l|}{2018} \\
\hline & & $-0,1702$ & B & 0,3626 & $\mathrm{H}$ & 0,0868 & $\mathrm{H}$ & 0,0522 & $\mathrm{H}$ & 0,2256 & $\mathrm{H}$ \\
\hline 2 & ECII & 1,8318 & $\mathrm{H}$ & 1,1913 & $\mathrm{H}$ & 0,9864 & $\mathrm{H}$ & 1,0442 & $\mathrm{H}$ & 1,098 & $\mathrm{H}$ \\
\hline 3 & GLOB & 0,8381 & $\mathrm{H}$ & 0,7547 & $\mathrm{H}$ & $-8,7132$ & $\mathrm{~B}$ & $-8,5942$ & $\mathrm{~B}$ & 0,0488 & $\mathrm{H}$ \\
\hline 4 & KOIN & 0,5438 & $\mathrm{H}$ & 0,3655 & $\mathrm{H}$ & 0,8924 & $\mathrm{H}$ & 0,2259 & $\mathrm{H}$ & 0,1561 & $\mathrm{H}$ \\
\hline 5 & MPPA & 0,7981 & $\mathrm{H}$ & 0,505 & $\mathrm{H}$ & 0,3361 & $\mathrm{H}$ & $-1,3436$ & $\mathrm{~B}$ & $-0,7432$ & B \\
\hline 6 & RIMO & $-2,1391$ & B & 38,3297 & $\mathrm{H}$ & 27,0677 & $\mathrm{H}$ & 0,3039 & $\mathrm{H}$ & $-0,0665$ & B \\
\hline 7 & SKYB & 0,1959 & $\mathrm{H}$ & 1,148 & $\mathrm{H}$ & 3,7674 & $\mathrm{H}$ & $-25,2102$ & $\mathrm{~B}$ & $-37,0562$ & B \\
\hline 8 & TRIO & 1,4055 & $\mathrm{H}$ & $-6,8738$ & $\mathrm{~B}$ & $-18,0629$ & $\mathrm{~B}$ & $-3,9906$ & $\mathrm{~B}$ & $-4,6309$ & $\mathrm{~B}$ \\
\hline
\end{tabular}

Financial distress prediction using the Grover model in 2014 is predicted to have 6 companies in good health and 2 of them in a bankruptcy state. Meanwhile, in 2015, 7 companies are predicted to be in good health and 1 company is in a bankrupt state. In 2016, 6 companies are predicted to be in good health and 2 companies are predicted to be bankrupt, while in 2017 
4 companies are predicted to be in a condition and the rest are predicted to be bankrupt. And 2018 is the same as in 2017.

4. Accuracy Test of Financial Distress Prediction Model

The actual state of the entire study sample was not delisted. Test the accuracy of the financial distress prediction model:

Table 6 Accuracy-Test of Financial Distress Prediction Model

\begin{tabular}{|c|c|c|c|}
\hline \multirow{2}{*}{ Calculation } & \multicolumn{3}{|c|}{ Financial Distress Prediction Model } \\
\hline & Altman Z-Score & Zmijewski & Grover \\
\hline Level of Accuracy & 15 & 28 & 27 \\
\hline Tyре II Error & 25 & 12 & 13 \\
\hline Total & 40 & 40 & 40 \\
\hline \multirow{2}{*}{ Calculation } & \multicolumn{3}{|c|}{$\begin{array}{c}\text { Financial Distress Prediction } \\
\text { Model }\end{array}$} \\
\hline & $\begin{array}{l}\text { Altman Z- } \\
\text { Score }\end{array}$ & Zmijewski & Grover \\
\hline Level of Accuracy & $37,5 \%$ & $70,00 \%$ & $67,50 \%$ \\
\hline Type II Error & $62,5 \%$ & $30,00 \%$ & $32,50 \%$ \\
\hline Total & $100,0 \%$ & $100,00 \%$ & $100,00 \%$ \\
\hline
\end{tabular}

Based on the accuracy test of the financial distress prediction model that has been carried out, it is known that the Zmijewski model is a model that has a high accuracy level of $70 \%$ and the smallest error rate is $30 \%$, the Grover model is $67.5 \%$ with an error rate of $32.5 \%$, and The Altman Z-Score model is $37.5 \%$ for the level of accuracy while the error rate is $62.5 \%$.

\section{Conclusion}

Based on the analysis and discussion of the research results, the conclusions are:

1. According to the company's Altman Z-Score model, GLOB, KOIN, MPPA, and TRIO need to be careful because they are classified as bankrupt or financial difficulties for two consecutive years or more. Zmijewski's model predicts that KOIN and MPPA companies are in financial distress and according to Grover's model, the companies' MPPA, SKYB, and TRIO are in financial distress. Companies need to evaluate their performance during the current period to make decisions so that the company does not go bankrupt. Financial distress in companies certainly affects investors due to the reaction of the capital market, especially when the company is declared delisted.

2. The results of the study indicate that the Zmijewski model produces the best predictions with an accuracy rate of $70 \%$. The second rank is Grover with $67.5 \%$. The Altman Z-Score model is ranked last with an accuracy rate of $37.5 \%$. 


\section{References}

[1] F. Saragih and A. Dewi, "Perbandingan Metode Springate dan Zmijewski dalam Memprediksi Kebangkrutan pada Perusahaan Ritel yang Terdaftar di Bursa Efek Indonesia," Festiv. Ris. Ilm. Manaj. Akunt., vol. 6681, pp. 16-21, 2016.

[2] K. A. R. I. Laksmana and A. Darmawati, "Analisis Uji Akurasi Model Grover, Springate, dan Zmijewski dalam Memprediksi Kebankrutan Perusahaan Delisted di BEI,” J. Magister Manaj. Unram, vol. 8, no. 1, pp. 62-72, 2019.

[3] I. W. Siregar, "Pengaruh Prediksi Kebankrutan Model Altman terhadap Opini Audit Going Concern," 2015.

[4] Fadrul and Ridawati, "Analysis of Method Used to Predict Financial Distress Potential in Pulp and Paper Companies of Indonesia," Int. J. Econ. Dev. Res., vol. I, no. 1, pp. 57-69, 2020.

[5] G. P. Tahu, "Predicting Financial Distress of Construction Companies in Indonesia: A Comparison of Altman Z-Score and Springate Methods," IJSEGCE, vol. 2, no. 2, pp. 7-12, 2019.

[6] A. Aminian, H. Mousazade, and O. I. Khoshkho, "Investigate the Ability of Bankruptcy Prediction Models of Altman and Springate and Zmijewski and Grover in Tehran Stock Exchange,” Mediterr. J. Soc. Sci., vol. 7, no. 4, pp. 208-214, 2016.

[7] A. Agarwal and I. Patni, "Bankruptcy Prediction Models : An Empirical Comparison," no. 6, pp. 131-139, 2019.

[8] E. N. Huda, P. D. Paramita, and D. Amboningtyas, "Analisis Financial Distress dengan Menggunakan Model Altman, Springate dan Zmijewski pada Perusahaan Retail yang Terdaftar di BEI Tahun 2013-2017," J. Manage., pp. 1-11, 2017.

[9] A. Kamaluddin, N. Ishak, and N. F. Mohammed, "Financial Distress Prediction Through Cash Flow Ratios Analysis," Int. J. Financ. Res., vol. 10, no. 3, pp. 63-76, 2019.

[10] F. Metal, A. Pertapan, S. Hartono, I. Aryati, and D. Purnomo, "Bankruptcy Prediction in PT Blue Bird , Tbk 2011-2016 Using Altman Z-Score , Springate , and Zmijewski Model,” Int. Conf. Technol. Educ. Soc. 2018, vol. 2018, no. 10, pp. 203-212, 2018.

[11] W. Nurcahyanti, "Studi Komparatif Model Z-Score Altman, Springate dan Zmijewski dalam Mengindikasikan Kebangkrutan Perusahaan yang Terdaftar di BEI," J. Akunt., 2015.

[12] R. T. Hastuti, "Analisis Komparasi Model Prediksi Financial Distress Altman, Springate, Grover dan Ohlson pada Perusahaan Manufaktur yang Terdaftar di Bursa Efek Indonesia Periode 20112013," J. Ekon., vol. XX, no. 03, pp. 446-462, 2015.

[13] H. E. Zulaecha and A. Mulvitasari, "Pengaruh Likuiditas, Leverage, Dan Sales Growth Terhadap Financial Distress," J. Manaj. Bisnis, vol. 8, no. 1, pp. 16-23, 2019.

[14] O. Andre and S. Taqwa, "Pengaruh Profitabilitas, Likuiditas, dan Leverage Dalam Memprediksi Financial Distress ( Studi Empiris Pada Perusahaan Aneka Industri yang Terdaftar di BEI Tahun 2006-2010 )," J. WRA, vol. 2, no. 1, pp. 293-312, 2014. 